\title{
Article/Artigo
}

\section{Restriction enzyme analysis of the human cytomegalovirus genome in specimens collected from immunodeficient patients in Belém, State of Pará, Brazil}

\author{
Análise de restrição enzimática do genoma viral do citomegalovírus humano em espécimes clínicos \\ de pacientes imunodeficientes, Belém, Estado do Pará

\section{Dorotéa Lobato da Silva ${ }^{1}$, Renato Lopes Fernandes de Medeiros ${ }^{1}$, Marluce Matos de Moraes ${ }^{1}$ and Fernanda Sagica do Espírito Santo ${ }^{1}$}

\begin{abstract}
Introduction: Human cytomegalovirus is an opportunistic betaherpesvirus that causes persistent and serious infections in immunodeficient patients. Recurrent infections occur due to the presence of the virus in a latent state in some cell types. It is possible to examine the virus using molecular methods to aid in the immunological diagnosis and to generate a molecular viral profile in immunodeficient patients. The objective of this study was to characterize cytomegalovirus genotypes and to generate the epidemiological and molecular viral profile in immunodeficient patients. Methods: A total of 105 samples were collected from immunodeficient patients from the City of Belém, including newborns, hemodialysis patients, transplant recipients and HIV+ patients. An IgG and IgM antibody study was completed using ELISA, and enzymatic analysis by restriction fragment length polymorphism (RFLP) was performed to characterize viral genotypes. Results: It was observed that $100 \%$ of the patients had IgG antibodies, $87 \%$ of which were IgG+/IgM-, consistent with a prior infection profile, $13 \%$ were $\mathrm{IgG}+/ \mathrm{IgM}+$, suggestive of recent infection. The newborn group had the highest frequency (27\%) of the IgG+/IgM+ profile. By RFLP analysis, only one genotype was observed, gB2, which corresponded to the standardAD169 strain. Conclusions: The presence of IgMantibodies in newborns indicates that HCMV continues to be an important cause of congenital infection. The low observed genotypic diversity could be attributed to the small sample size because newborns were excluded from the RFLP analysis. This study will be continued including samples from newborns to extend the knowledge of the general and molecular epidemiology of HCMV in immunodeficient patients. Keywords: Cytomegalovirus. Immunodeficient. Genotypic diversity. Viral DNA. RFLP.
\end{abstract}

\section{RESUMO}

Introdução: O citomegalovírus é um betaherpesvírus oportunista, causador de infecções persistentes e graves em pacientes imunodeficientes. As infecções recorrentes ocorrem devido à presença do vírus em estado de latência, em alguns tipos celulares, o que possibilita a pesquisa viral por métodos moleculares para auxiliar nos diagnósticos imunológicos, assim como traçar o perfil epidemiológico e molecular viral em pacientes imunodeficientes. O objetivo deste estudo foi caracterizar os genótipos de citomegalovírus e traçar o perfil epidemiológico e molecular viral em pacientes imunodeficientes. Métodos: Um total de 105 amostras foi coletado de pacientes imunodeficientes da Cidade de Belém, incluindo recém-nascidos, hemodialisados, transplantados e pacientes HIV+. Foi realizada a pesquisa de anticorpos IgG e IgM pelo método ELISA e análise enzimática pelo método restriction fragment length polymorphism (RFLP) para caracterização dos genótipos virais. Resultados: Foi observado que $100 \%$ dos pacientes apresentavam anticorpos IgG, 87\% eram IgG+/IgM- perfil de infecção pregressa; e $13 \%$ IgG+/ IgM+ sugestivo de infecção recente. $\mathrm{O}$ grupo dos recém-nascidos apresentou maior frequência (27\%) do perfil IgG+/IgM+. Na análise por RFLP, foi observado um único genótipo, o gB2, que corresponde ao padrão genotípico da cepa AD169. Conclusões: A presença de anticorpos IgM nos recém-nascidos indica que o vírus CMV continua sendo causa importante de infecção congênita; a baixa diversidade genotípica pode ser atribuída ao tamanho amostral devido a exclusão dos recém-nascidos na análise por RFLP. Esse estudo será continuado incluindo amostras de recém-nascidos a fim de contribuir para um amplo conhecimento da epidemiologia geral e molecular do citomegalovírus em pacientes imunodeficientes da Cidade de Belém.

Palavras-chaves: Citomegalovírus. Imunodeficiente. Diversidade genotípica. DNA viral. RFLP.

1. Seção de Meio Ambiente, Instituto Evandro Chagas, Secretaria de Vigilância Sanitária, Ministério da Saúde, Ananindeua, PA.

Address to: Dra. Dorotéa Lobato da Silva. Lab. Virologia e Biologia Molecular/IEC/SVS/MS. BR 316, $\mathrm{km} \mathrm{7,67030-000} \mathrm{Ananindeua,} \mathrm{PA,} \mathrm{Brasil.}$

Phone: 5591 3214-2092

e-mail: dorotealobato@iec.pa.gov.br

Received in 21/09/2010

Accepted in 22/03/2011

\section{INTRODUCTION}

Human cytomegalovirus ( $\mathrm{HCMV}$ ) is an opportunistic betaherpesvirus that causes serious and persistent infections in immunodeficient patients ${ }^{1-3}$. Secondary infections occur by viral reactivation from latency in some cell types and transplanted organs or by reinfection ${ }^{4-8}$. This persistent nature of HCMV infection facilitates the use of molecular and immunological diagnostic tools. It also allows the molecular and epidemiological profiling of virus isolates from individuals with risk factors for infection, such as immunosuppression and living in an underdeveloped country where the HCMV seroprevalence is elevated ${ }^{9-13}$.

Molecular analyses by restriction fragment length polymorphism (RFLP) and sequencing of the glycoprotein $\mathrm{B}(\mathrm{gB})$-encoding region of the HCMV viral envelop are used as basic tools for genotypic classification of the virus and the association between genotypes and immunodeficient patient categories as assessed by clinicians ${ }^{14-24}$. Rasmussen associated this genotypic variability with graft rejection in liver transplant patients and with the level of neutropenia in organ recipients, which can result in death.

A study of the genotypic distribution of HCMV reported that the $\mathrm{gB} 2$ genotype is the most frequent in asymptomatic kidney transplant patients, bone marrow transplant patients with infections and asymptomatic premature babies ${ }^{17}$. Bale et al. observed an association between the gB3 genotype and in utero infection with a severe clinical outcome of cytomegaly. Trincado et al. identified the gB1, $\mathrm{gB} 2$ and gB3 genotypes in utero infected babies, children with perinatal infection and HIV-positive patients, respectively. Ahumada-Ruiz et al. described 53 polymorphics standards distributed between the gB1, gB2 and gB3 genotypes in HIV seropositive individuals, blood donors, alcoholics, pregnant women, children with leukemia and in utero infected newborns. The neonatal group was the only group 
that presented three of the four HCMV genotypes. Based on these analysis tools, Chou \& Dennison and Meyer-König et al. classified the HCMV gB genotypes into four distinct groups: gB1, gB2, gB3 and $\mathrm{gB} 4$.

The objective of this study was to genotypically characterize HCMV isolates from immunodeficient patients by RFLP of the $\mathrm{gB}$ region. We sought to relate different viral genotypes to groups of immunodeficient patients and to trace their molecular epidemiological profiles.

\section{METHODS}

From 2005-2006, 105 blood samples were selected from immunodeficient patients suspected of HCMV infection by requesting these samples from the attending clinical and epidemiologic at the Instituto Evandro Chagas. The selected categories were hemodialysis patients using corticosteroids $(\mathrm{n}=30)$; kidney transplant patients $(\mathrm{n}=30)$; HIV-positive patients $(\mathrm{n}=15)$; and newborns suspected of TORCH infections $(n=30)$. The analysis of $\operatorname{IgG}$ and $\operatorname{IgM}$ antibodies was performed using the Diassorin ELISA serological method according to the manufacturer's recommendations. The IgM+ samples were further amplified by PCR and individually digested with HinfI or RsaI enzimes. Viral DNA was extracted from the leukocytes of IgM+ patients with the GFX Genomic Blood DNA Purification Kit from Amersham Biosciences. In the PCR reaction, primers $\mathrm{P}_{1}-1319$ and $\mathrm{P}_{2}-1604$ (Chou \& Dennison) were used to amplify a 296-bp region of the gene encoding the viral envelope protein $\mathrm{gB}$. The PCR reaction was composed of sterile water, primers, dNTP mix, $\mathrm{MgCl}_{2}$, Taq Polymerase and extracted DNA. The amplification conditions were identical to those used by Chou \& Dennison. The GeneAmp 9700 PCR System thermocycler from Applied Biosystems was used.

After the amplification step, the samples were analyzed by electrophoresis in a $1 \%$ agarose gel and visualized under ultraviolet light using the Vilber Lourmert ${ }^{\circledR}$ photodocumentation system. The amplified DNA bands were compared with the positive control and the molecular weight markers. Amplified DNA samples were digested with HinfI and RsaI enzimes under the following conditions: $37^{\circ} \mathrm{C}$ for $180 \mathrm{~min}, 65^{\circ} \mathrm{C}$ for $10 \mathrm{~min}, 25^{\circ} \mathrm{C}$ for $20 \mathrm{~min}$, followed by incubation at $4^{\circ} \mathrm{C}$.

The sizes of the RsaI fragments that designate HCMV genotypes are as follows: GB1 66-239 bp, GB2 63-239 bp, GB3 63-195 bp and GB4 66-195 bp; with HinfI: GB1 67-202 bp; GB2 100-202 bp; GB3 97-202 and GB4 67-202. The visualized DNA fragments were compared with the undigested and digested fragments from the AD169 strain and the 50- and 100-bp molecular weight markers.

\section{RESULTS}

The results of the ELISAs of the 105 samples selected for this study revealed that $100 \%$ of the samples were IgG positive. Of these, $87 \%$ of the patients had previously come in contact with the virus and therefore had the immunological profile of $\operatorname{IgG}$ positive and $\operatorname{IgM}$ negative, and $13 \%$ presented concomitant $\operatorname{IgG}$ and $\operatorname{IgM}$ antibodies, suggestive of recent infection.

The immunological status of each subgroup of patients is shown in Table 1. The anti-HCMV antibody prevalence was elevated in all of
TABLE 1 - Immunological status of the analyzed patient sub-groups.

\begin{tabular}{|c|c|c|c|c|c|c|c|c|}
\hline \multirow[b]{2}{*}{ Antibodies } & \multicolumn{2}{|c|}{$\mathrm{RN}$} & \multicolumn{2}{|c|}{ Hemodialysis } & \multicolumn{2}{|c|}{ HIV+ } & \multicolumn{2}{|c|}{ Transplanted } \\
\hline & $\mathrm{n}$ & $\%$ & $\mathrm{n}$ & $\%$ & $\mathrm{n}$ & $\%$ & $\mathrm{n}$ & $\%$ \\
\hline IgG +/IgM- & 22 & 73.0 & 28 & 93.3 & 13 & 87.0 & 28 & 93.3 \\
\hline $\mathrm{IgG}+/ \mathrm{IgM}+$ & 8 & 27.0 & 2 & 6.7 & 2 & 13.0 & 2 & 6.7 \\
\hline Total & 30 & 100.0 & 30 & 100.0 & 15 & 100.0 & 30 & 100.0 \\
\hline
\end{tabular}

RN: newborn, HIV: Human immunodeficiency virus, IgG: immunoglobulin G, IgM: immunoglobulin M.

the patient groups with the IgG+/IgM-immunological profile more frequent in hemodialysis and kidney transplant patients (both with 93.3\% frequency). The newborn group had a greater IgG+/IgM+ profile frequency $(27 \%)$, indicating congenital infection. The other groups had $\mathrm{IgG}+/ \mathrm{IgM}+$ percentages of $6.7 \%$ (hemodialysis) and $13 \%$ (transplant), correlating with acute HCMV infection in two individuals in each of those groups (Table 1).

It was not possible to obtain satisfactory results from PCR amplification of the newborn samples; therefore, this group was excluded from the RFLP analyses. The other IgM+ samples were digested using the HinfI and RsaI restriction enzymes to characterize HCMV genotypes (total of 6 samples). Figure 1 is an image of a representative gel with the results from the enzimatic digests of the three cited groups (hemodialysis, transplant and HIV+). From left to right, the samples are as follows: $1^{\text {st }}$ and last well are the 50-bp and 100-bp molecular weight markers, which confirm the sizes of the restriction fragments. The $11^{\text {th }}$ and $12^{\text {th }}$ wells contain the DNA of the AD169 strain digested by RsaI and HinfI enzimes, respectively. The $13^{\text {th }}$ well contains the undigested AD169 strain, which represents an amplification standard. From the $2^{\text {nd }}$ well, the digests of clinical samples are shown, in order of patient number with alternating RsaI and HinfI in successive lanes. The clinical samples were compared with the 50-bp molecular weight ladder ( $1^{\text {st }}$ well on the left of the gel) and the gB2 positive control DNA of Strain AD169 digested with both enzymes. All RsaI fragments from clinical samples were sized from 250-200 bp.

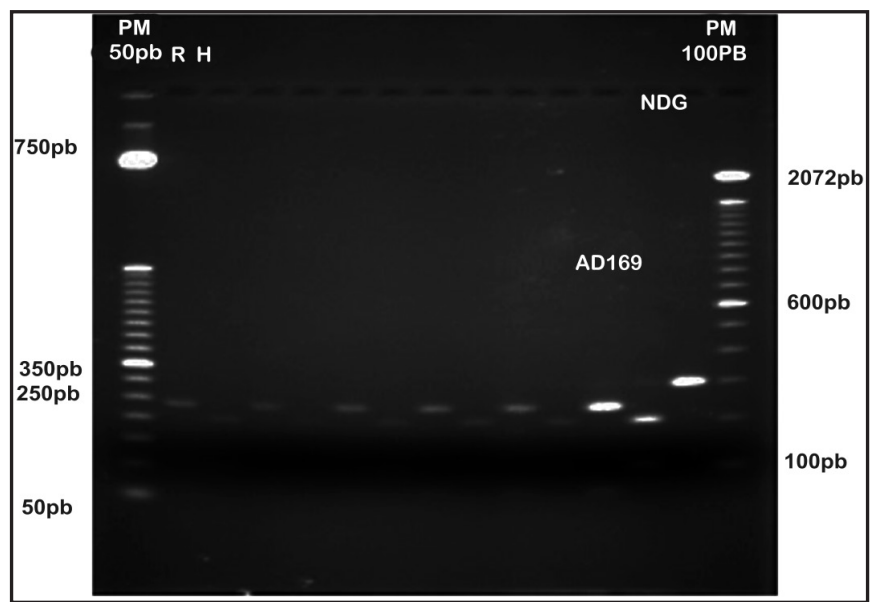

FIGURE 1 - PCR products digested by restriction enzymes.

PM 50bp: 50bp molecular weight marker, R: enzyme Rsa I, H: enzyme Hirf I, NDG: sample without digestion, PM 100bp: 100bp molecular weight marker.

The analysis of the RsaI fragment bands confirms the samples with the possible $\mathrm{gB} 1$ and $\mathrm{gB} 2$ genotypes because the fragments generated with HinfI are located between the 200- and 150-bp bands. Based on the HinfI and RsaI digest results of clinical samples compared to the AD169 control strain, we concluded that all of the digested samples belong to the gB2 genotype. These data are presented in Figure 1. 
The combined molecular and serological analyses are presented in Table 2. Only 6 samples were positive for HCMV infection by both methods. By serology, 13.3\% ( $n=14)$ of samples were positive for the recent infection profile, whereas only $5.7 \%(n=6)$ were positive for viral DNA indicative of active HCMV infection. No statistically significant difference was observed between the results of the two laboratory methods by Fisher's exact test $(\mathrm{p}>0.05, \mathrm{~F}=0.0061$, degrees of freedom $=1$ ).

TABLE 2 - Results of the serological and molecular analyses.

\begin{tabular}{lcc}
\hline \multirow{2}{*}{ PCR } & \multicolumn{2}{c}{ Serological } \\
\cline { 2 - 3 } & $\begin{array}{c}\text { positive } \\
\text { (infection) }\end{array}$ & $\begin{array}{c}\text { negative } \\
\text { (without infection) }\end{array}$ \\
\hline Negative & 8 & 97 \\
\hline Positive & 6 & 0 \\
\hline Total & $\mathbf{1 4}$ & $\mathbf{9 7}$ \\
\hline PCR: polymerase chain reaction. & &
\end{tabular}

\section{DISCUSSION}

The results of the ELISA analyses of the 105 samples selected for the study demonstrated that $100 \%$ of the patients had IgG antibodies and $13 \%$ had $\operatorname{IgM}$ antibodies, which is the profile $(\operatorname{IgG}+/ \operatorname{IgM}+)$ suggestive of a recent HCMV infection.

The presence of $\operatorname{IgG}$ antibodies in the absence of $\operatorname{IgM}$ in immunosuppressed patients does not necessarily represent a good prognosis, because HCMV is an opportunistic pathogen that can reactivate in the presence of IgG antibodies. The immunosuppressed state of these individuals, in addition to drug therapy during the treatment of their main disease, also favors the occurrence of a possible secondary infection by a new viral strain. The elevated frequency of $\operatorname{IgG}$ antibodies and absence of IgM antibodies in the investigated patients is compatible with the immunological and epidemiological profile of a low socio-economic level and of Latin American countries where the HCMV seroprevalence is elevated ${ }^{6,9,11}$.

Among the newborns, transplant recipients, hemodialysis patients and HIV carriers selected for analysis, the presence of IgG antibodies was observed at elevated frequencies in all individuals. Newborns were the most affected group with profiles suggestive of congenital infection in $27 \%$ of the investigated babies. These results highlight the importance of prenatal HCMV diagnosis along with other toxoplasmosis, rubella, cytomegalovirus and herpes (TORCH) agents and epidemiological monitoring of HCMV-infected newborns. Although no molecular analysis was completed on newborns in the present study, the $\mathrm{gB}$ genotype has been associated with congenital infections. Bale et al. described this association after RFLP analysis of the gpUL55 region of $g B$, in which a greater frequency of the $\mathrm{gB} 3$ genotype was observed in utero infected children with severe clinical signs of cytomegaly.

The PCR positivity did not reach the expected values as found in the serological analysis, possibly due to the difficulty in amplifying samples from the newborns. Although the difference was not statistically significant, we noted some disadvantages of the molecular method compared to the serological method. These differences relate to the difficulties in amplifying certain biological specimens, which can be due to the presence of inhibitors in the PCR reaction or poor sample quality. For newborns, there were difficulties in the quantity and quality of the analyzed material, and for this reason, this group was excluded from the molecular analysis.
The analysis by RFLP showed that the samples belonged to a single genotype group, gB2, which corresponds to the standard genotype of the AD169 strain (also the control for this analysis). Our findings are consistent with those from Chou and Woo et al. with regard to the presence of $\mathrm{gB} 2$ in immunodeficient individuals. Woo et al. observed a greater frequency of the $\mathrm{gB} 2$ genotype in bone marrow transplant recipients with HCMV-associated symptoms. In contrast, Fries et al. and Trincado et al. associated the gB1 genotype with immune deficiency.

Aquino \& Figueiredo among others described high frequencies of the $\mathrm{gB} 1(61.8 \%)$ and $\mathrm{gB} 3$ genotypes $(58.8 \%)$ in kidney recipients with gB2 in the minority of samples (41.2\%). Simultaneously, 70.6\% of the individuals carried more than one $\mathrm{gB}$ genotype. Coaquette et al. described similar data with regard to the prevalence of the gB1 (28.9\%), gB3 (23.7\%) and gB2 genotypes (19.6\%) in a group of immunocompromised patients; more than one gB genotype per patient was also observed in these individuals. Our findings do not confirm the results observed by Trincado et al., Aquino \& Figueiredo or Coaquette et al., likely due to the lower sample size analyzed in the present study. Small sample sizes may not be sufficient to observe HCMV genotypic diversity by PCR and RFLP, especially in samples from newborns, which are difficult to obtain. This study should be extended with a greater number of samples, including samples from newborns; it may then be possible for these data to contribute to the general epidemiological and molecular understanding of HCMV based on immunodeficient patients in the City of Belém.

\section{CONFLICT OF INTEREST}

The authors declare that there is no conflict of interest.

FINANCIAL SUPPORT

Instituto Evandro Chagas Institute, Secretaria de Vigilância em Saúde/Ministério da Saúde.

\section{REFERENCES}

1. Pannuti CS. Citomegalia. In: Veronesi R, Focaccia R, editors. Veronesi: Tratado de Infectologia. São Paulo: Atheneu; 1996. p. 187-194.

2. Trincado DE, Scott GM, White PA, Hunt C, Rasmussen L, Rawlinson WD Human Cytomegalovirus strains associated with congenital and perinatal infections. J Med Virol 2000; 61:481-487.

3. Cannon MJ. Congenital Cytomegalovirus (CMV) epidemiology and awareness. J Clin Virol 2009; 46 (suppl 4):6-10.

4. Stainer P, Debra LT, Alan DK, Nicholas W, Yvonne-Tryhorn A, Stanley TYMS Persistence of Cytomegalovirus in mononuclear cells in peripheral blood from blood donors. Br Med J 1989; 897-898.

5. Chou S, Dennison K. Analisys of interstrain variation in cytomegalovirus glycoprotein B sequences encoding neutralization-related epitopes. J Infect Dis 1991; 163:1224-1234.

6. Bale FJ, Murph JR. Intrauterine Cytomegalovirus infection and glycoprotein B genotypes. J Infect Dis 2000; 182:933-936.

7. Ahumada-Ruiz S, Taylor-Castillo L, Visona K. Determination of human cytomegalovirus genetic diversity in different patient populations in Costa Rica. Rev Inst Med Trop 2004; 46:87-92.

8. Coaquette A, Bourgeosis A, Dirand C, Varin A, Chen W, Herbein G. Mixed cytomegalovirus glycoprotein $\mathrm{B}$ genotypes in immunocompromised patients. Clin Infect Dis 2004; 39:155-161. 
9. Gomez ER, Betancourt AM, Cruz PS, Calvo PS, Avilés EV. Prevalencia de seropositividad a Citomegalovirus em pacientes com neoplasias hematológicas. Rev Inst Nac Cancerol 1992; 38:1695-1699.

10. Taylor-Wiedeman J, Hayhurst GP, Sissons JGP, Sinclair JH. Polymorphonuclear cells are not sites of persistence of human cytomegalovirus in healthy individuals. J Gen Virol 1993; 74:265-268.

11. Mocarski Jr ES. Cytomegaloviruses and their replication. In: Knipe DM, Howley PM, Griffin DE, Lamb RA, Martin MA, Roisman B, et al, editors. Fields Virology. $3^{\text {th }}$ ed. Philadelphia: Lippincott-Raven; 1996. p. 2447-2492.

12. Grosjean J, Hantz S, Cotin S, Baclet MC, Mengelle C, Trapes L, et al. Direct genotyping of Cytomegalovirus envelope glycoproteins from toddler's saliva samples. J Clin Virol 2009; 46 (suppl 4):43-48.

13. Rodrigues CEM, Gadelha CS, Nobre CA, Callado MRM, Vieira RMRA, Vieira WP. Retinite por Citomegalovirus (CMV) após terapia imunossupressora para vasculite leucocitoclástica. Rev Bras Reumatol 2009; 49:64-69.

14. Candeias JAN, Klaus ES, Barbosa V. Estudo sorológico de infecções ocasionadas por Citomegalovírus. Rev Saude Publica 1974; 8:257-263.

15. Fries BC, Chou S, Boeckh M, Torok-Storb B. Frequency distribuition of cytomegalovirus genotypes in boné marrow transplant recipients. J Infect Dis 1994; 169:769-774.

16. Guimarães KCC, Andrade CVC, Oliveira Jr VF, Carvalho LB, Linhares MIS. High prevalence of Citomegalovirus seropositivity in children with acute lymphoid leukemia in Recife, Northeast Brazil. An Fac Med Fed 1997; 42:13.

17. Woo PCY, Lo CY, Lo SKF, Siau H, Peiris M, Wong SSY, et al. Distinct genotypic distributions of Cytomegalovirus (CMV) envelope glycoprotein in boné marrow and renal transplant recipients with CMV disease. Clin Diag Lab Immunol 1997; 3:515-518.

18. Almeida LNB, Azevedo RS, Amaku M, Massad E. Cytomegalovirus seroepidemiology in an urban community of São Paulo, Brazil. Rev Saude Publica 2001; 35:1-12.

19. Silva DFL, Gomes RHS, Moraes MM, Medeiros RFL, Santos ECO, Jesus IM. Perfil sorológico da infecção pelo Citomegalovirus em pacientes transplantados de Belém-Pará. Cad Saude Coletiva 2007; 15:369-378.

20. Junqueira JJM, Sancho TM, Santos VA. Citomegalovírus: Revisão dos aspectos epidemiológicos, clínicos, diagnósticos e de tratamento. Newslab 2008; 86:88-104.

21. Rasmussen L. Molecular pathogenesis of human cytomegalovirus infection. Transpl Infect Dis 1999; 1:127-134.

22. Meyer-Konig U, Haberland M, Von Laer D, Haller O, Hufert FT. Intragenic variability of human Cytomegalovirus glycoprotein B in clinical strain. J Infect Dis 1998; 177:1162-1169.

23. Pannuti CS. Infecção por Citomegalovírus. Pediat 1984; 6:144-153.

24. Aquino VH, Figueiredo LTM. High prevalence of renal transplant recipients infected with more than one Cytomegalovirus glycoprotein B genotype. J Med Virology 2000; 61:138-142. 